\title{
Pesquisa-experimentação com imagens, palavras e sons: forças e atravessamentos
}

\author{
ALIK WUNDER \\ DAVINA MARQUES \\ ANTONIO CARLOS RODRIGUES DE AMORIM
}

\section{Resumo}

Dizeres, imagens e sons reconhecem-se apenas como riscos, rastros..., como um desejo de acompanhar um ritmo irrepresentável, de desenhar outra gramática. Neste artigo, tecemos pensamentos com o vídeo Fabulografias criado a partir dos encontros-oficinas-saraus na relação com os escritos sobre fabulação, acontecimento e sensação de Gilles Deleuze, principal intercessor dos projetos de pesquisa e de criação artística que atravessam essas experiências. A

Palavras-chave: Acontecimento, experimentação, audiovisual pesquisa se dá não somente através daquilo que podemos dizer ou escrever, mas principalmente através daquilo que construímos, em experimentações, em com-posições. 


\title{
Experiment-research with images, words and sounds: strengths and traverses
}

\author{
ALIK WUNDER \\ DAVINA MARQUES \\ ANTONIO CARLOS RODRIGUES DE AMORIM
}

\begin{abstract}
Sayings, images and sounds are recognized only as scratches, traces..., as a wish to follow an unrepresentative step, to design another grammar. In this article we have weaved thoughts with the video Fabulografias, which was created from materials produced in meetings and workshops, in their relation to the writings on story-telling, event and sensation by Gilles Deleuze, the main intercessor in the research projects and artistic creation that traverse these experiences. The research takes place not only accordingly to what we may say or write about it, but mainly through what we have built in experimentation, in com-positions.
\end{abstract}

Keywords:

Event, experimentation, audiovisual 


\title{
Investigación experimentación con imágenes, palabras y sonidos: fuerzas y cruces
}

\author{
ALIK WUNDER \\ DAVINA MARQUES \\ ANTONIO CARLOS RODRIGUES DE AMORIM
}

\section{Resumen}

Narraciones, imágenes y sonidos se reconocen apenas como arañones, huellas..., como un deseo de acompañar un ritmo irrepresentable, de esbozar otra gramática. En este artículo, tejemos reflexiones sobre el video Fabulografias creado a partir de los encuentros-talleres-saraos relacionados con los escritos sobre fábulas, acontecimientos y sensaciones de Gilles Deluze, principal intercesor de los proyectos de investigación y de creación artística que atraviesan esas experiencias. La

Palabras-clave: Acontecimiento, experimentación, audiovisual investigación acontece, no solamente a través de aquello que podemos decir o escribir, sino principalmente a través de aquello que construimos, en experiencias, en com-posiciones. 
Fabular por entre ventos áfricas. Fabular por entre ventos alegres e tristes que vazam. Encontrar novos modos de encontrar e criar com imagens e palavras. Que áfricas ventam por você? Que áfricas ventam nas escolas, nos grupos artísticos, nas ruas, nas universidades? Como compor com as multiplicidades afro-brasileiras que nos atravessam? Um fabular de áfricas em que potencializam-se encontros e criações com poemas, fotografias e vídeos, com artistas, grupos de cultura popular, estudantes, professores e pesquisadores em experimentações coletivas. Aproximações entre arte, educação e pesquisa. Chamamos pelas áfricas que perpassam pessoas, áfricas que são imaginadas a partir dos frágeis indícios que nos restaram. Áfricas fabuladas no interior de um silêncio que paira na cidade. Como ecoar vida desde dentro desse silêncio oco?

OO:O0: Voz em off, abertura do vídeo Fabulografias'. Da tela negra a uma luz pueril e multicolor. Entre rápidos fremes, o filme oferece, nas primeiras cenas, lampejos fugidios, parte de objetos - máscaras, saias, fotografias, espelhos, óculos, búzios -resquícios de gestos, moventes sombras, luzes e cores. No transe de instantâneos imagéticos, desejos de captura de frágeis indícios de gestos, coisas e seres que escapam da tela. Sensações impalpáveis, impossibilidade de captura do gesto, do giro, do som, das forças...

Entre poesia e filosofia, ressonâncias. O poeta Manoel de Barros lança, no livro Ensaios Fotográficos, um desejo: "queria transformar o vento, dar ao vento uma forma concreta e apta a foto. Eu precisava pelo menos encontrar uma parte física do vento. Mas a forma do vento me fugia que nem as formas de uma voz." (BARROS, 2011, p.385-386). Gilles Deleuze, filósofo, lança-nos inquietações no livro Lógica da Sensação: "não se trata de reproduzir ou inventar formas, mas de captar forças.” 

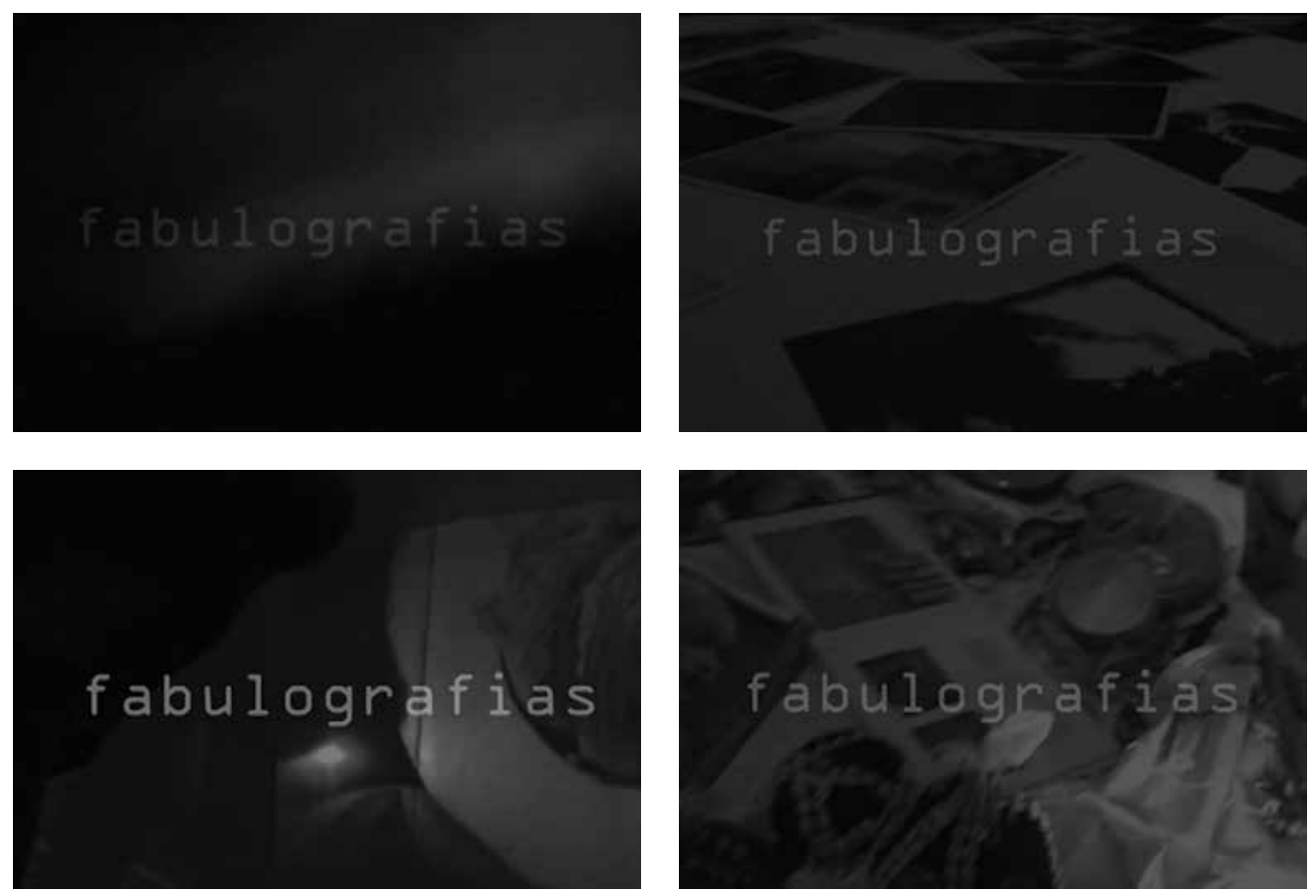

(DELEUZE, 2007, p. 62). Para o filósofo, a tarefa da arte - pensando neste capítulo com a música e a pintura de Francis Bacon - é tornar visíveis forças que não são visíveis, fazer sentir forças insensíveis. Como pintar ou fazer ouvir o Tempo, que é insonoro e invisível? (DELEUZE, 2007). Com o filósofo e o poeta, lançamos as perguntas de pesquisa: Como vibrar imagens e sons em superfícies de passagem e atravessamento de forças? Como enveredar pela via de criação sensível?

O que desafia a escrita deste artigo é pensar a pesquisa com imagens em educação a partir de um movimento de pensamento e criação imagética do grupo de estudos Humor Aquoso, ligado ao Laboratório de Estudos Audiovisuais OLHO, da Faculdade de Educação da Universidade Estadual de Campinas (SP). Pensando com Gilles Deleuze e Félix Guattari, Eugénia Vilela e Fernando Bárcena, Daniel Lins, entre muitos, para nos deixar atacar por conceitos, atravessamentos, forças e ressonâncias entre pessoas, imagens, palavras e sons nos processos de criação de um vídeo experimental de pesquisa intitulado Fabulografias.

O projeto de pesquisa "In-ventos por entre áfricas, literaturas e imagens" ${ }^{\prime 2}$ ao qual o vídeo está relacionado, envolve-se a um projeto maior "Intervalar o currículo: potências das 
audiovisualidades"3. Nesses projetos, pretende-se compor um plano para pensar a educação e a imagem, que articule o acontecimento com os conceitos de sensação, fabulação e vida. No encontro com obras de artísticas, busca-se criar linhas de associação e de composição criativas com os conceitos da filosofia de Gilles Deleuze e Félix Guatarri e de outros estudiosos do campo da produção cinematográfica, fotográfica e estética visual. No grupo de estudos Humor Aquoso, as escritas em iniciações científicas, mestrados, doutorados e demais projetos de pesquisa e extensão fazem-se imbricadas a movimentos de experimentação com imagens e com conceitos filosóficos. Os percursos de pesquisa movem-se de formas diversas pelo tríptico -educação, arte e filosofia, dedicando-se especialmente ao estudo das imagens - cinema, pintura, fotografia, performance, literatura - em busca de políticas visuais, em que as imagens não sejam representações de certa visibilidade ótica, mas criações de outras visualidades, intensidades que desequilibrem modos de pensar a educação, a arte, a linguagem, a cultura, o sujeito, a identidade. Interessam-nos as intensidades, as formas em desfiguração, as forças insensíveis, a abertura de brechas para a junção de heterogêneos sentidos, de invenções, de fabulações (AMORIM, 2013). Interessa-nos inventar modos singulares de pensar com as palavras e com as imagens, em escritas de pesquisas como abertura de espaços:

[...] para que floresçam as ambiguidades e a incerteza da interpretação da realidade, pela íris da verdade. $\mathrm{O}$ convite que Deleuze e Guattari fazem à escrita é de ela devir música em movimento, e os dedos, ao invés de escreverem/digitarem, dançam, criam verdades que se possam dançar. Uma outra mirada para o conceito de verdade se faz necessária, tomando-o como múltiplo, "verdade intensiva idêntica à Vida: a verdade não faz mais objeto de uma 'pesquisa', mas torna-se o sujeito de uma afirmação que se encarna nas ideias e nos corpos sob uma forma intensiva" (LINS, 2004, p. 46).

Se a pesquisa não desvela a verdade, mas cria verdades intensivas e múltiplas que dançam, as imagens e as palavras da pesquisa perdem o peso de remeterem-se a contextos, fatos, olhares, interpretações, narrativas vividas. Pulverizam-se escritas dançarinas em que as imagens e as palavras entrelaçam-se em ressonâncias imprevisíveis. São movimentos de experimentação do "pensamento em diapasão com a diferença, que acolhe a diferença como um saber alheio a recognição: como 
estética-acontecimento.” (LINS, 2012, p. 21). Daniel Lins diz que não existe estética como acontecimento deslocado de sua força inventiva:

A estética como acontecimento pode ser percebida como aplicação-experimentação de sua concepção de pensar, e, da arte como pura invenção: devir e não cópia. O contrário, pois, da descoberta de uma verdade, de uma natureza pré-existente ou de uma vontade de fazer um dogma, uma opinião, privando-se de seu devir e de seu movimento, produtor de sopros, passagens, confluências, ondas e tubos gigantes, catedrais aquáticas, ferramentas peculiares à transformação e à transvalorização de todos os valores. (2012, p. 20).

Pensar a educação como campo problemático, inventando conceitos para dar vazão a forças insensíveis a certos modos de ver, ouvir e pensar, é um desejo que nos persegue. Desafiamo-nos a inventar, com a arte e com a filosofia, modos outros de acessar e capturar forças, reconhecendo a pesquisa e a educação como atos de criação e resistência. Uma criação que se dá na invenção de conceitos, que não representam o mundo, não exprimem verdades ou afirmam opiniões (LINS, 2012), mas que rasgam a língua e o pensamento para expor novos problemas e, com as potências da arte, fazem vazar forças indizíveis, invisíveis e imprevisíveis.

Entre as linhas intensivas do pensamento com as produções audiovisuais, há uma provocativa tensão entre o documento e o real ficcionado, entre o registro e a invenção de espaços e tempos. Uma aglutinação espaçotemporal. Ato da imagem de roubar nossa atenção. Narrar sem legenda. Criar com a imagem a lenda fabulatória de um mundo que se abre às forças do tempo. As imagens são, especialmente, um motivo para se estender um território vivo para o pensamento paradoxal persistir. Sem resolver entre uma e outra parte, aposta-se no meio, nas fendas e nos interstícios da criação. E quando as imagens, em pesquisa, fabulam em meio à indiscernibilidade entre registro e ficção? Que potências ganham? Que outras forças e atravessamentos agenciam?

Como ecoar vida desde dentro de um silêncio oco?

A frase ressoa, repete-se e se multiplica em ecos no vídeo $\mathrm{Fa}$ bulografias. Existe o silêncio, sabemos do silenciamento das vozes por entre áfricas. Há cinco anos, desde 2010, realizamos 
movimentos de criação coletiva com fotografias, poemas, sons e vídeos em torno das ressonâncias múltiplas da cultura afro-brasileira. O projeto de pesquisa "In-ventos por entre áfricas, literaturas e imagens" e o Núcleo de Leitura Fabulografias-ALB ${ }^{4}$ envolvem pesquisa e oficinas-saraus de leitura, escritas, criações de fotografias e vídeos, em um fabular de áfricas por escolas, universidades, espaços culturais, praças, museus. Nos encontros entramos em um processo coletivo de experimentação com universitários, pesquisadores, professores e alunos de escolas públicas, fotógrafos, dançarinos, músicos, artistas populares, um coletivo fluido e movente que chamamos de Coletivo Fabulografias ${ }^{5}$, composto por todos aqueles que um dia participaram e foram atravessados pelos fluxos de pesquisa e invenção.

O experimentar que buscamos dá-se transversado pela pulsão poética das palavras e das imagens e também pelas experiências de vida - encantamentos, desejos, resistências, silêncios, tensões - forças que cada participante traz. Um experimentar que prevê uma atmosfera apta ao encontro, um preparo de espaços-tempos sensíveis à diferença ainda sem nome, à palavra sem corpo, à imagem sem referente, a um silêncio que ecoa sem lugar no mundo das palavras e nas imagens conhecidas.

O convite às oficinas-saraus é feito com uma pergunta: Que áfricas ventam por você? Ao lançarmos a pergunta-convite, pedimos que sejam trazidos objetos, livros, notícias, fotografias, adereços, cenas, performances, cantos, histórias - como traços de respostas para compor os ensaios de criações literárias e fotográficas. E dos gestos de criação transbordam encantamentos, silêncios, tensões, clichês, dores, fascínios, curiosidades, desconhecimentos e preconceitos.

Oferecemos, no início de cada encontro - como forma de contágio - produções feitas em oficinas anteriores, produzindo um fluxo contínuo de poemas, fotografias e vídeos. Uma aposta na força que as imagens, palavras e sons disparam, sem a necessidade de contextualização, explicação ou mediação. Além das produções do Coletivo Fabulografias, poemas de escritores afro-brasileiros e de países africanos lusófonos, bem como produções fotográficas de artistas brasileiros e africanos compõem a ambiência dos espaços de encontro, que chamamos de banquetes de palavras e imagens. A inspirar. Ins-pirar. Sabores tantos, giros amplos... ${ }^{6}$

Entre criações fotográficas de performances, de objetos, de encenações, de composições de imagens e textos, de pessoas; entre escritas fragmentadas e coletivas a partir de fotografias, 
entre fotografias suscitadas pela leitura de poemas surge um espaço-tempo propício à abertura aos acontecimentos inesperados, aos encontros inusitados entre pessoas, imagens e palavras em gestos coletivos de criação. Faz-se um convite a escrever a partir do fragmento de um poema, a partir de uma fotografia, de um objeto, escrever ou fotografar na reverberação de uma história ouvida ou lida. A câmera fotográfica e filmadora do grupo ficam à disposição dos participantes para as capturas instantâneas de algo que acontece. O experimentar com poemas e fotografia é um gesto de abertura à multiplicidade e à diferença, à rajada imprevisível gerada no encontro com o "outro" do pensamento, da palavra, da imagem... Diferença que se faz pela criação artística, por operações que produzem uma distância, uma dessemelhança (RANCIÈRE, 2012, p.15).

Uma música de palavras, uma pintura com palavras, um silêncio nas palavras.

Gilles Deleuze

O vídeo Fabulografias é atravessado por fotografias, poemas, vídeos e vozes nesse fluxo de ressonâncias e forças dos encontros realizados. Compõe-se de criações de muitas pessoas, em vários fragmentos de edições que chamamos de vídeos-poema. O vídeo fez-se como uma composição movente entre palavras, imagens e sons que gestam e reconstroem acontecimentos. Suas conexões são tantas possíveis. Trata-se de uma multiplicidade atravessada por linhas. ${ }^{7}$ Os sentidos - significados e sensações - desdobram-se e permitem construir e reconstruir sobre o que foi aberto antes daquele momento, sem vetores, sem orientação prévia, em passagens múltiplas e mutantes. Entre contágios, capturar uma luz, um gesto, um som, uma voz. Uma aposta na metamorfose, nas dobras, e na primazia das forças sobre as formas.

O vídeo lida com o novo e leva em conta "a força de uma pluralidade de encontros como desencadeadores de disposições ou indisposições surpreendentes" (ORLANDI, 2011, p.148). Algo transborda na companhia dos signos. Na composição entre fragmentos daquilo que foi feito antes, um desejo de vibrar em ressonância com situações vividas, sem significá-las, buscando produzir forças a partir das reverberações dos contidos gritos, sussurros, silêncios das áfricas que nos perpassam. O envolvimento de músicos, artistas visuais, fotógrafos - estudantes de artes e artistas convidados - nas oficinas 
permitiu a produção de um potente material imagético e em áudio. A criação coletiva de vídeos ofereceu um olhar múltiplo e compartilhado que movimentou e afetou aqueles que se envolveram com as produções.

Trabalhamos com imagens em movimento de várias formas: na captação livre de cenas das oficinas de experimentação e das performances de artistas convidados; na edição de vídeos a partir das provocações das oficinas e como resultantes do envolvimento dos participantes; na elaboração de vídeos de pesquisa com a intenção de apresentar o projeto; na edição de sons e palavras de leituras de poemas; em composições musicais disparadas por imagens e por poemas; em experimentações de edição na ritmação de imagens e sons.

Esses experimentos se fizeram em ressonâncias e atravessamentos disjuntivos entre sons e imagens, poemas e sons, imagens e poemas. E que potências audiovisuais se abrem quando o som não ilustra as imagens e as palavras? Quando a imagem não representa o som? Quando os poemas não narram as imagens? Nas passagens ressonantes entre palavras, imagem e sons, como as forças adensam-se, atravessam-se em vídeo? E como dizer de reverberações entre sons-imagens-palavras em uma escrita?

Vibrar no eco do grito que já não se ouve na vertigem e na tensão desse silêncio oco
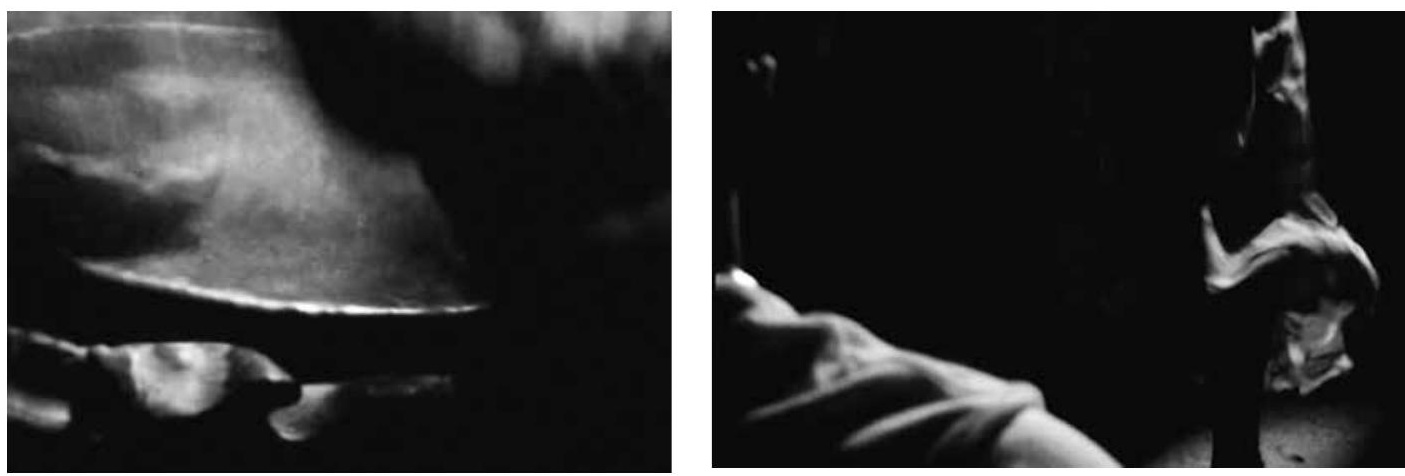

1:28: Do escuro um tambor, negras mãos em silencioso batuque. Elementos de percussão em provocativo desencontro com as mãos. Na disjunção entre o toque e o som ecoa um silêncio, um eco, um vazio. Sombras em movimento contam de uma dança de corpos não vistos. É preciso entrever, adivinhar as cadências, harmonias, tempos e sonoridades. Saias 
em redemoinhos, pés descalços marcando o chão, entre nós. Tambores e danças e cantos atravessados por poesia: Imagens, visagens, vertigens, ordens, (des)ordens, potências do múltiplo. Acontecimento.

Para Deleuze, o conceito de acontecimento está na ordem do resto da linguagem, naquilo que escapa à possibilidade de dizer. O acontecimento não é um fato ocorrido, mas um contínuo deslize da linguagem por aquilo que não se pode dizer em palavras, em imagens. É uma disjunção que se passa entre a linguagem e o mundo. A linguagem menos como uma comunicação de fatos e mais como um território atravessado pelo acontecimento. $\mathrm{O}$ acontecimento passa ao mesmo tempo pela linguagem e pelo mundo. [...] "O acontecimento é inseparavelmente o sentido das frases e o devir do mundo; é o que, do mundo, deixa-se envolver na linguagem e permite que funcione." (ZOURABICHVILI, 2004, p. 16-17).

Em Deleuze, o acontecimento não é o fato, não é o encontro de corpos, mas o incorpóreo, os sentidos e sem-sentidos que pairam em outro tempo como ressonâncias e dissonâncias das lógicas corpóreas. $\mathrm{O}$ acontecimento tem a ver com a emergência do novo pelo ato do pensamento, uma diferença inapropriável, e nela a possibilidade de contra-efetuação às condições materiais. Talvez a abertura de um intervalo, um vazio para aquilo que vem sem direção de causa ou de efeito - puros efeitos - para aquilo que simplesmente nos consome e nos inunda em um devir ilimitado. Paisagens imprecisas que se fazem nas intensidades, agitações e rupturas dos pequenos discursos emaranhados no avesso da ordenação normal dos fatos. Agitações que desequilibram discursos, rasgam o tecido harmônico de uma imagem totalizadora, traçam linhas descontínuas, fragmentadas, em desordem e liberam devires que não se fundam na ideia da origem. Assim, desfaz-se a crença de que seja possível encontrar no passado o acontecimento verdadeiro e que, por ele, possamos encontrar e nos apoiar em uma identidade fixa e estável. Não buscaríamos origens mesmo perdidas ou rasuradas, mas pegaríamos as coisas onde elas crescem, pelo meio: rachar as coisas, rachar as palavras. (DELEUZE, 1992, p.109).

À criação artística se colocou como desafio produzir um possível no impossível do dizer o acontecimento, vibrar na inquietação de um grito calado, buscando romper com as fronteiras reconhecidas da ordem discursiva (BARCENA; VILELA, 2006, p.15). Um "acontecimento no dizer, acontecimento do dizer”. (VILELA, 2012, p. 395). 
Algo acontece: é uma espécie de abismo - também a minha língua não acompanha o ritmo do acontecer - nem verdadeiro nem falso - verdadeiro e falso, a um só. [...] Procuro um signo que desenhe a gramática de sua irrupção, mas nessa gramática apenas se tece a ruína da origem e da palavra e da história. (VILELA, 2012, p. 410).

Entre ruínas, investimos em uma pesquisa que busca produzir pensamentos na experimentação, na pulsão irrepresentável do silêncio e do grito, nos abismos e irrupções nos modos conhecidos de dizer por palavras, imagens, sons. O grito. Berro calado. Se é pra lembrar, lembro a dor e o silêncio.

Eugénia Vilela e Fernando Bárcena (2006) escreveram do verbete Acontecimento para o Dicionário de filosofia da educação. Inicialmente passeando por palavras como eventual, casual, impossível, pela teoria das probabilidades, os autores afirmam que, em filosofia da educação, há dois sentidos mais centrais do termo: um como atualização de coordenadas no tempo presente; outro como algo que surge em uma determinada situação. Diferentemente de um fato, continuam os autores, os "acontecimentos são indizíveis, inimagináveis, inerarráveis, ou simplesmente inefáveis" (VILELA; BÁRCENA, 2006, p.15). Como, então, dizer do acontecimento? Vilela e Bárcena (2006, p.16) sugerem uma resposta a partir das conversações com Gilles Deleuze: "Dizer o acontecimento é nomear o que ocorre como dobra do real, como interrupção ou descontinuidade. É pensar o inesperado. Dizer, nomear, pensar o acontecimento é, num sentido amplo, ensaiar o nome de uma irrupção, de uma fratura no real."

O acontecimento como criação rompe fronteiras discursivas, aproxima diferenças. Nas imagens do vídeo potencializa-se o acontecimento como fratura, o que dá a pensar. Um pensamento radical. Simultaneamente essa afecção é também incorpórea. Exige o pensamento sem um sujeito agente, que desferiria sua interpretação ou experiência, transformando o acontecimento em experiência cognoscível. Abrem-se as imagens e os sons pensantes, fraturando nas relações entre sujeito e objeto os efeitos do tempo das virtualidades, a caoticidade inventiva. No caos da criação das imagens reafirma-se um pensamento em disjunção. Poético, sem controle. Perder o controle.

In-ventos de áfricas. In-venta-se no poético, onde o "olhar capta o próprio instante daquilo que surpreende" (VILELA; BÁRCENA, 2006, p.19). 


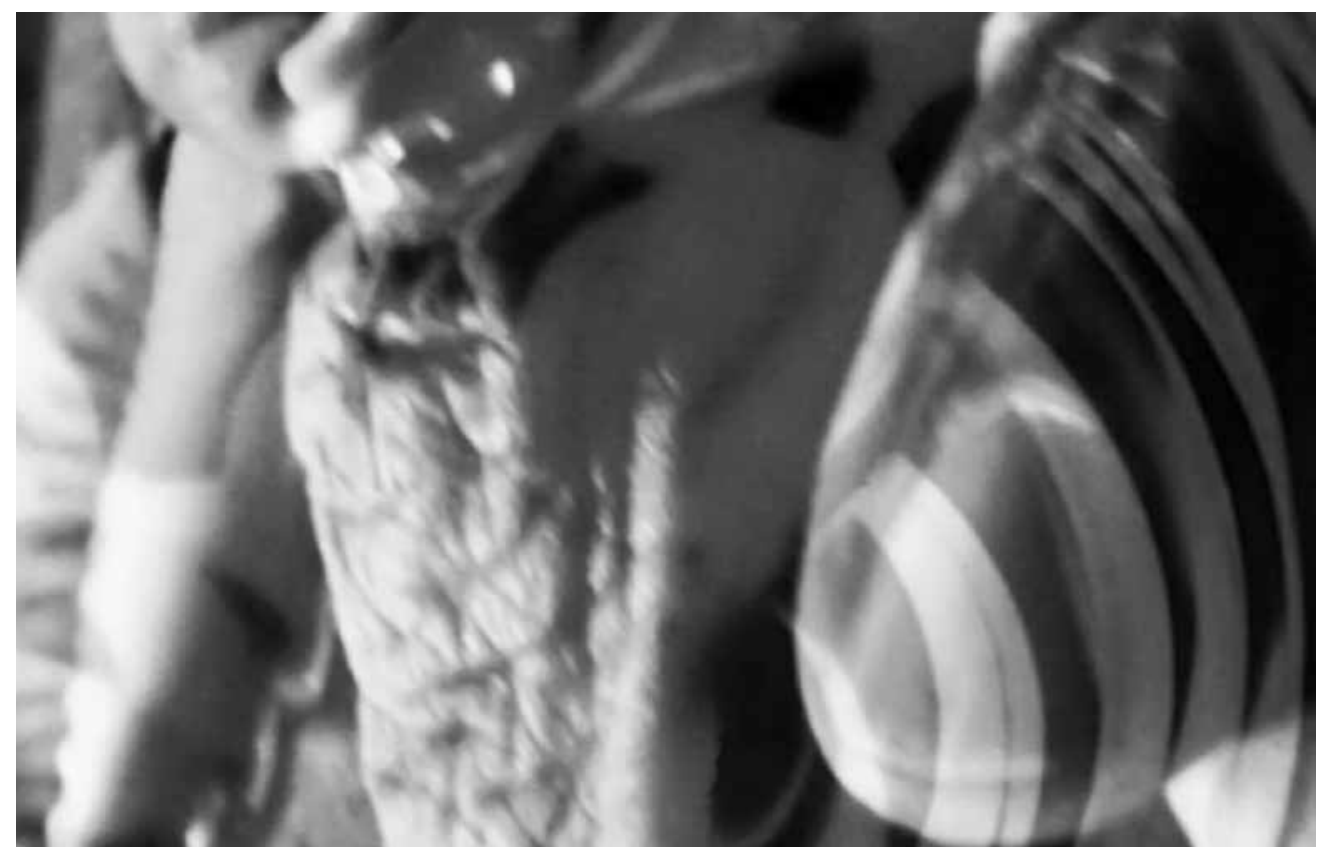

2:49：Recortes de uma mão, marcas do tempo na pele, sobreposições de traços, cores, anel, brilho, búzio. Uma pausa, uma tensa suspensão. Pesa na imagem o som de um baixo acústico em ladainha e cintilam em variação as notas do piano. Destoantes camadas sonoras fazem a câmera dançar lentamente por texturas: pele áspera, negra, opaca, cintilações do azul e do claro das conchas. Em transe, as imagens e os sons sobrepõem-se e fazem girar um redemoinho. Nele atravessam-se as forças da leveza e do peso. Voltam as mãos, outras mãos, em flashes ritmados pelas notas musicais. Rosto-menina, rosto-máscara de flandres, rosto-riso, rosto-silenciado em sobreposição de tempos, experiências, singularidades... Leveza e peso aglutinados. Nos poucos segundos para entrever a composição, o vídeo é atravessado por um transe, um grito sonoro e imagético.

Qual o som do grito no antes da garganta?

Poderíamos dizer, com Vilela (200o, p. 45) que os acontecimentos transformam-se em memória viva, quando se permite ser tocado. Onde toca esse grito sonoro e visual? O que reverbera o caos visual e sonoro ao vazar o insuportável? Que rela- 
ção de forças suscitam? Do caos da experimentação organiza-se um diagrama, uma catástrofe, mas também um germe da ordem e de ritmo (DELEUZE, 2007, p.104):

É preciso considerar o caso especial do grito. Porque Bacon vê no grito um dos mais elevados objetos da pintura? "Pintar o grito...”: não se trata de modo algum de dar cores a um som particularmente intenso. A música encontra-se diante da mesma tarefa, que não é tornar o grito harmonioso, mas de colocar o grito sonoro em relação com as forças que o suscitam [...] Quando se grita, é sempre graças a forças invisíveis e insensíveis que embaralham todo espetáculo, que transbordam até mesmo a dor e toda a sensação. O que Bacon exprime dizendo: "pintar o grito menos que o horror". Se fosse exprimi-lo em um dilema, se diria: ou pinto o grito e não o horror visível, e pintarei assim cada vez menos o horror visível, pois o grito é a captura ou a detecção de uma força invisível. (DELEUZE, p. 65-66).

A composição expõe os atravessamentos e permite afetar e ser afetado. Palavras-águas-vivas. Qual o som do grito no antes da garganta? Na experimentação, surge uma estética: a estética como acontecimento. A "Est-Ética, ou estética como acontecimento, é a arte de exigir da vida algo mais forte do que ela nos proporciona." (LINS, 2012, p.18). Não nos interessa a proteção contra o caos, preferimos o mergulho no caos, coabitar o caos, desfazer representações.

Me gritaron negra! Victoria Santa Cruz

5:42: Devir-outro, explicitar marcas em uma individualidade em construção, transfiguração, deformação sobre os rostos. Individuação. Um agenciamento coletivo, múltiplas vozes. A leitura dramática do poema "Me gritaron negra", de Victoria Santa Cruz. A força da palavra sentida em língua estrangeira. A batida ritmada e forte. A ramificação do individual no imediato-político. O berro, agora não calado, ofensivo, forte, provoca. Na composição com as imagens das experimentações do nosso coletivo, reforçam a urgência de se lidar com a violência do pensar a-referenciado do tema das africanidades. Um encontro de corpos - imagem e palavra - sensíveis, violentos e ruidosos. O movimento desejante percorre e configura uma estética do desconforto, que desassossega olhares que buscam 

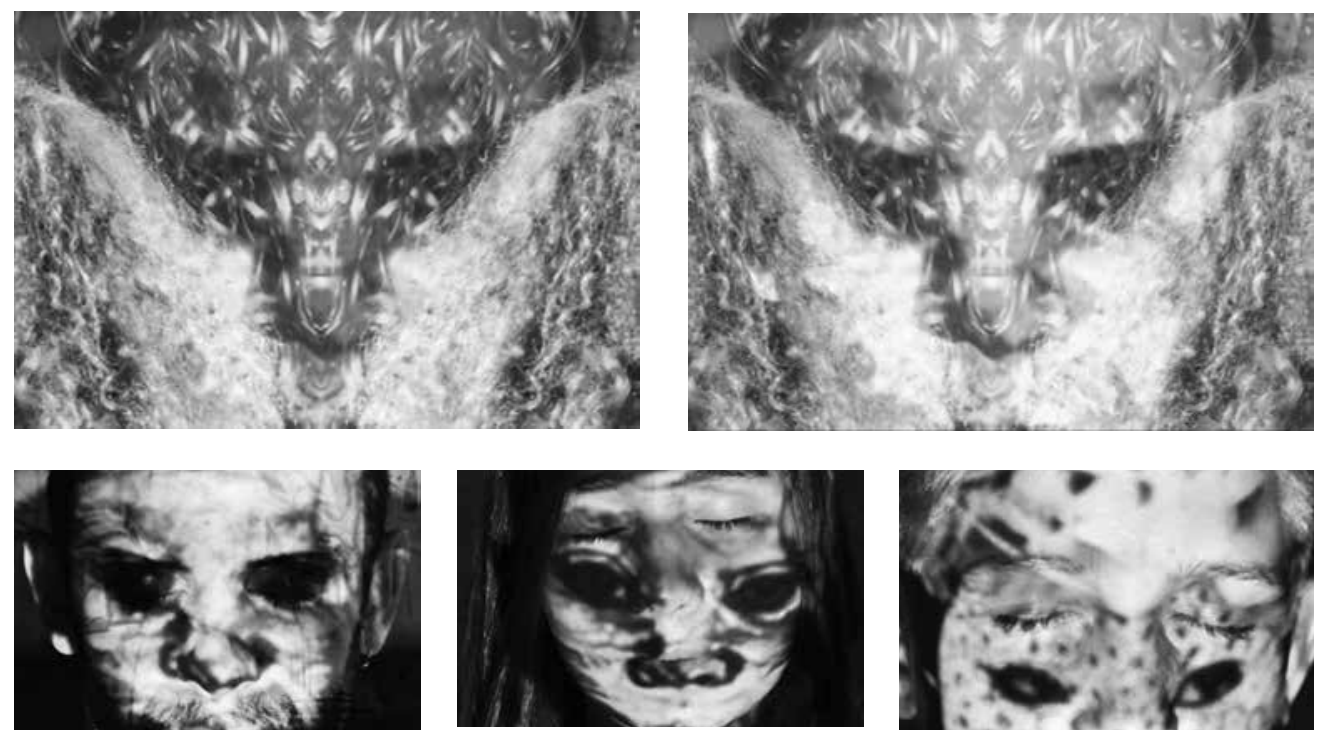

perspectivar o acontecimento. Por muitas vezes, ao invés de nos prometer o registro de "eu estive lá", a conjunção imagem e palavra realça a pergunta de "por que estão aqui", juntas, na fabricação textual que clama por realidade.

A tarefa da pintura é definida como a tentativa de tornar visíveis as forças que não são visíveis. Da mesma forma que a música se esforça para tornar sonoras forças que não são sonoras. Isso é evidente. A força tem uma relação estreita com a sensação: é preciso que a força exerça sobre um corpo, ou seja sobre um ponto da onda, para que haja sensação [...] A música deve tornar sonoras as forças insonoras, e a pintura, visíveis forças invisíveis. (DELEUZE, 2007, p.62).

11:41: Frenética ritmação entre imagens e sons... Dançam cores e corpos-carne-viva, em espasmos. As imagens, sons gritam, não representam o grito. Entram em transe, no non-sense dos espasmos, das vozes, rostos e peles em variação, indefinição, em arruinamento. Os corpos não são pessoas, são forças, agenciamento de forças; as peles não são identidades, são aglomerados de signos - pele- negra, pele-branca, pele-rósea, pele-carne-viva, pele-sombra, pele-azul, pele-bicho, pele-árvore, pele-chão, pele-planta. Corpos-cores, corpos-sons, corpos-gestos, corpos-sons gritam o irrepresentável. Desejo de criar marcas livres nos corpos identitários, de formas preenchidas. 'Trata-se de esquecermos a incidência perversa da 'forma' 

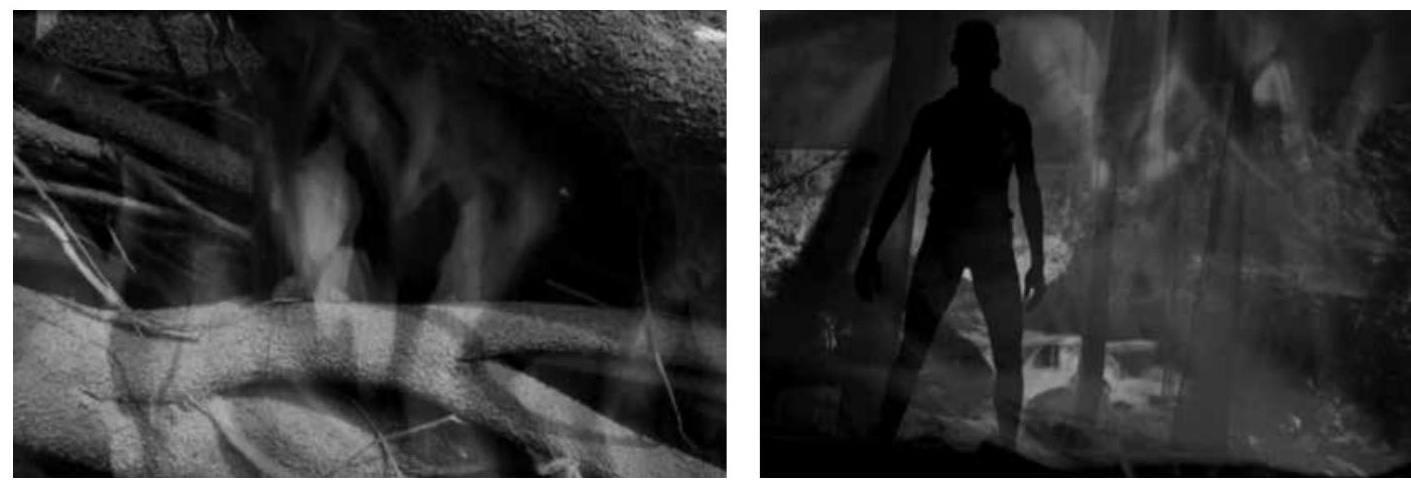

- ação, que opera em retomar a visibilidade da forma - e capturarmos as forças de um corpo que escapa em silêncio, que se individua em fragmentos tão e que despertam inorgânicos da violência intervalar do exílio." (AMORIM, 2013, p. 424).

Será preciso fazer rapidamente 'marcas livres' no interior da imagem pintada para destruir a figuração nascente e dar chance à Figura, que é o próprio improvável. Essas marcas são acidentais, 'ao acaso' [...] Pode-se dizer que essas marcas são não-representativas, justamente porque dependem do ato ao acaso e nada exprimem que se refira à imagem visual, elas só dizem respeito à mão do pintor. Mas por isso só servem para serem utilizadas pela mão do pintor, que vai se servir delas para extrair a imagem visual do clichê nascente. E se servirá das marcas manuais para fazer surgir a Figura da imagem visual. Do princípio ao fim, o acidente, $o$ acaso nesse segundo sentido, terá sido ato, escolha, um determinado tipo de ato e escolha. É o acaso manipulado, diferente das possibilidades concebidas e vistas. (DELEUZE, 2007, p.97-98).

As cores e ritmos dão às imagens do vídeo uma ordenação das forças em caos "para que os meios violentos não se desencadeiem e que a catástrofe necessária não inunde tudo" (DELEUZE, 2007, p.112), as forças vibram em velocidades diversas. Rapidez e lentidão, peso e leveza, sombras e cintilações, causam um desmoronamento de coordenadas visuais e sonoras, "labora[m] com sentidos: pele, toque, forças erógenas, embriaguez-abstêmia, alheias à significação ou à representação." (LINS, 2012, p.20). "É como o nascimento de um outro mundo. Pois estas marcas, estes traços, são irracionais, involuntários, acidentais, livres, ao acaso. Eles não são representativos, não ilustrativos, não narrativos." (DELEUZE, 2007, p.103). 
O vídeo convida a experimentar um olhar nômade que se deixa envolver por algo (des)conhecido, envolve-se em afetos, aceita a surpresa...

Ventô o vento que chama vento

$O$ vento vai balançar...

Experimentamos aqui ensaiar uma cartografia do vídeo. Leve. Ainda sob efeito daquilo que nos mobiliza e afeta nesse projeto e em seus desdobramentos:

Fazer uma cartografia não significa repetir ou copiar, mas, evidenciar modos para gerar nossos próprios processos, nossos próprios conceitos, principalmente a partir de uma filosofia grávida de múltiplos olhares e travessias outras. No fundo, a cartografia é a arte da busca. No entanto, neste caso, buscar, pesquisar, é um procedimento não da ordem da imitação, do calco; tem a ver com a imaginação, a intuição, a polifonia [...]. (LINS, 2012, p.22).

Em pesquisa-experimentação, o vídeo foi se organizando por caminhos menores. Menor, um conceito inicialmente apresentado por Deleuze e Guattari $(1977$, p.28) ao falar sobre os escritos de Franz Kafka, funciona aqui para pensarmos aquilo que, como a obra do escritor, desterritorializa a língua, promove a ramificação do individual no imediato-político, organiza-se em um agenciamento coletivo de enunciação. Tem a ver, portanto, com a organização de forças que causam estranhamento, uma espécie de desorganização do estabelecido, um susto, algo difícil de ser capturado, copiado, reproduzido, arquitetado a priori.

Discordamos de que tudo se trataria de uma ficção, na/ pela audiovisualidade, de que as produções precisem ser passíveis de uma subjetivação que se abre pela imaginação... As audiovisualidades-invenções não produzem corpos coletivos. Na dinâmica do acontecimento, são enunciados que se apropriam dos corpos e "os desviam de sua destinação na medida em que não são corpos no sentido de organismos, mas quase-corpos, blocos de palavras circulantes sem pai legítimo que os acompanhe até um destinatário autorizado" (RANCIÈRE, 2009, p. 6o). Assim compreendidas, as audiovisualidades recolocam em causa a partilha do sensível, afirmando uma política que introduz nos corpos imaginários linhas de fratura, de desincorporação. "Desenham comunidades aleatórias que 
contribuem para a formação de coletivos de enunciação que repõem em questão a distribuição dos papéis, territórios e das linguagens”. (RANCIÈRE, 2009, p. 6o). Um coletivo desincorporado, caracterizado pelas lacunas, e inconcluso. O tempo presente como foco do desenrolar das histórias. As narrativas transformam-se em conversações, o imaginário em imagens em ação, e as imagens-corpos que significam pela representação habitam brechas, à espreita e aguardando o inesperado.

Apostamos na mediação e no estupor da audiovisualidade, em toda sua força contra-interpretativa e povoada de grafias que não se restituiriam no olhar. Tanto incertas quanto instáveis, as audiovisualidades permitem, na pesquisa em educação, fazer circular, adensar, atravessar e acontecer nos textos acadêmicos a hibridização dos sujeitos e objetos, criando outra via de sua figuração, a do corpo-imagem, sem o desejo de resolver o paradoxo entre o orgânico (da identidade, por exemplo) e a arte da fabulação (do ficcional ou irreal, por exemplo). Uma aposta como companhia nestes projetos de pesquisa: as imagens abrem-se à presença de ruídos, sombras, pontos fora da perspectiva, um mundo às avessas e de ponta-cabeça.

A educação pode assumir a intencionalidade desse esforço humano de significação do silêncio e da voz daqueles que são os Outros. Pela comunicação dessa memória através da arte, enquanto único introdutor possível de todos os universos concentraccionários, será possível construir uma memória exemplar que é, afinal, um lugar de resistência [...] A resistência é uma ética dos que estão vivos (VILELA, 2000, p.52).

do escuro

um tambor negras mãos silencioso batuque sombras em movimento danças de corpos não vistos vigor firmeza prazer negros corpos negras mãos envolventes encontros entre-ver vistar adivinhar 


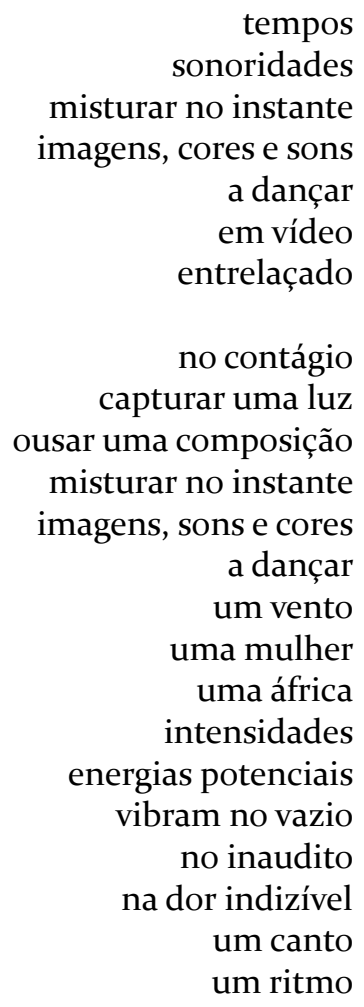

vibrar no eco do grito

que já não se ouve

na tensão

deste silêncio oco

oco

OCO

um vento que vaza

em oblíqua resistência

e nos vaza em sonse imagens

gestos no espaço vibram a pele

desenham o som do vento

o brilho na superfície

estopim para visagens do dedo

em outros gestos

cores em sons,

brilho em palavra

vermelhidão

de uma dança 
de uma sombra que se vai e de outras tantas que vêm como as nuvens de uma noite

silêncios em vozes gritos em sussurros corpos criados como a gota que escorre, venta

compor um desenho sonoro em movimento soar diferentes matizes de forças

venta o (i)material sons em cores, cores de sons cintilam imagens

leve

leva

sons

imagens

tons

sutil neblina insinua vontades percute desejos inventa começos e outros tantos meios

em vozes de cores de gestos de luz nas breves ternuras absurdas murmuram resmungos do que toca no que toca e na pele vibra e se mistura vai e vem de um aqui ou ainda mais de um lá de onde venta de onde vem 
venta

venta um gesto

que rasga

um território de uma sensação em luz

no inaudito

algo de um ausente

vento em movimento

voz

qual o som do grito no antes da garganta?

oco sonoro

implosão

berro calado

soco no estômago

gosto de sangue

surda explosão

gaguejados gritos

despojar sentidos e expor sobras

farrapos

fios

fibrosas farpas

ouvir grunhidos

no antes da forma

do som

da coisa

resta uma poeira suspensa e dissolvida

que luz

se escuridão?

o som

colore o tom

faz ecoar na palavra a cor

o som

o tom

o silêncio

o grito

o vento

NOTAS

1. Disponível em: <https://www.youtube.com/watch?v=2NL12JnNNVs >. Fabulografias é um vídeo resultante de pesquisa na área de Educação, Conhecimento, Linguagem e Arte como desdobramento do projeto de extensão 
"Fabulografias em áfricas-cartões-postais" (FAEPEX - Unicamp) com o grupo de estudos Humor Aquoso. O vídeo foi selecionado para a I Mostra de Curtas - Vídeos de Pesquisa da ANPED (2015).

2. Edital Ciência Sociais e Humanas do CNPq e PAPDIC/Unicamp.

3. Edital Universal CNPq 2013 (Proc. 484908/2013-8), sob coordenação do Prof. Antonio Carlos Amorim.

4. O Núcleo de Leituras Fabulografias-ALB possibilita o contato de jovens de escolas públicas e de comunidades não-escolares com as dimensões estéticas da literatura e das artes visuais e estimula a criação com palavras e imagens, em especial, com a poesia e com a fotografia. Foi criado em 2012 por meio da parceria entre a Associação de Leitura do Brasil, a Faculdade de Educação-Unicamp e o Movimento por um Brasil Literário. Mais informações no blog: <http://fabulografias-alb.blogspot.com.br/>.

5. Diante do convite a experimentações coletivas que o projeto faz, reconhecemos todas as fotografias, vídeos e poemas, frutos dos processos inventivos, de autoria coletiva. A autoria desloca-se, assim de uma posição individual para o Coletivo Fabulografias.

6. Os trechos em itálico de todo o texto, sem referências, são de poemas do Coletivo Fabulografias.

7. Deleuze e Guattari, ao apresentarem as características do rizoma, discutem o princípio da multiplicidade como a perda da relação com o uno = sujeito ou objeto. No nosso projeto, não temos sujeito e objeto, "somente determinações, grandezas, dimensões que podem crescer sem que mude[m] de natureza" (DELEUZE; GUATTARI, 1995, p.16-17).

\section{Referências}

AMORIM, Antonio Carlos. Três crianças a compor um plano para o currículo. Currículo sem Fronteiras, v. 13, n. 3, p. 411426, set./dez. 2013.

BARROS, Manoel de. Poesia Completa. São Paulo: Leya, 2011. DELEUZE, Gilles. Conversações. Tradução Peter Pál Pelbart. São Paulo: Ed. 34, 1992.

. Francis Bacon: Lógica da Sensação. Trad. Roberto Machado (coord.). Rio de Janeiro: Zahar, 2007.

DELEUZE, Gilles; GUATARRI, Félix. Kafka: por uma literatura menor. Tradução Julio Castañon Guimarães. Rio de Janeiro: Imago, 1977.

. Mil platôs: capitalismo e esquizofrenia. Volume 1. Tradução Aurélio Guerra. São Paulo: Ed. 34, 1995.

LINS, Daniel. Juízo e Verdade em Deleuze. São Paulo: Annablume, 2004.

LINS, Daniel. Estética como Acontecimento. In: DIAS, Susana O.; MARQUES, Davina; AMORIM, Antonio Carlos. Conexões: Deleuze e Arte e Ciência e Acontecimento e... Petrópolis/RJ; Brasília/DF; Campinas/SP: De Petrus; CNPq/ MCT; ALB, 2012. p. 17-36.

RANCIÈRE, Jacques. O destino das imagens. Tradução Môni- 
ca Costa Netto. Rio de Janeiro: Contraponto, 2012.

VILELA. Eugénia. Corpos Inabitáveis. Errância, Filosofia e Memória. Enrahonar, 31, p.35-52, 2000.

Silêncios Tangíveis: corpo, resistência e testemunho nos espaços contemporâneos do abandono. Porto: Edições Afrontamento, 2012.

VILELA, Eugénia; BÁRCENA, Fernando. Acontecimento. In: CARVALHO, Adalberto Dias de (Coord.). Dicionário de filosofia da educação. Porto: Porto Editora, 2006. p.14-19.

ZOURABCHVILI, François. O vocabulário de Deleuze. Rio de Janeiro: Relume-Dumará, 2004.

Recebido em: 09/07/15

Aceito em: 10/10/15 


\section{ALIK WUNDER \\ alik.wunder@gmail.com}

Professora da Faculdade de Educação da Universidade Estadual de Campinas (UNICAMP), no Departamento de Educação, Conhecimento, Linguagem e Arte. Pesquisadora do Laboratório de Estudos Audiovisuais (Olho) e pesquisadora colaboradora no Laboratório de Estudos Avançados em Jornalismo (Labjor).

\section{DAVINA MARQUES \\ davinamarques@hotmail.com}

Doutora em Letras e Mestre em Educação, Professora do Instituto de Educação, Ciência e Tecnologia de São Paulo (IFSP), Campus Hortolândia. Líder do Experimentações: Núcleo de Pesquisa em Leituras, Escritas e Imagens e pesquisadora colaboradora do Laboratório de Estudos Audiovisuais (Olho).

\section{ANTONIO CARLOS RODRIGUES DE AMORIM acamorim@unicamp.br \\ Professor Livre-Docente, Associado 2 (MS-5.2) da Universidade Estadu- al de Campinas (UNICAMP), no Departamento de Educação, Conhe- cimento, Linguagem e Arte, pesquisador e vice-líder do Laboratório de Estudos Audiovisuais (Olho) e pesquisador associado no Laboratório de Estudos Avançados em Jornalismo (Labjor). Pesquisador 1 C do CNPq.}

